\title{
Contribution of Microscopy to Clarify the Mechanism of Ni-Ti Phases Formation During Re- active Sintering
}

Pavel Novák ${ }^{1}$, Pavel Salvetr ${ }^{1}$, Kateřina Nová ${ }^{1}$, Jaromír Kopeček ${ }^{2}$, Miroslav Karlík ${ }^{3}$, Davy Deduytsche ${ }^{4}$, Christophe Detavernier $^{4}$, Lucyna Jaworska ${ }^{5}$

${ }^{1}$ University of Chemistry and Technology, Prague, Department of Metals and Corrosion Engineering, Technická 5, 166

28 Prague 6, Czech Republic, E-mail: panovak@vscht.cz

${ }^{4}$ Ghent University, Department of Solid State Sciences, Krijgslaan 281 S1

9000 Gent, Belgium

${ }^{5}$ Institute of Advanced Manufacturing Technology, 37a Wroclawska St., 30-011 Krakow, Poland

NiTi alloy exhibits the shape memory effect, which implies the application in medicine and also many industrial branches. This paper is devoted to the manufacture of these alloys by the use of powder metallurgy using reactive sintering. This method could enable easier production of this alloy and achievent of higher purity. However, for the optimization of this technology, the deeper knowledge of the mechanism of the process is needed. This work uses microscopy on real powder mixtures subjected to reactive sintering, as well as on model samples processed under various conditions.

Keywords: NiTi, reactive sintering, mechanism, microscopy

\section{Acknowledgement}

This research was financially supported by Czech Science Foundation, project No. 14-03044S. Partial support by COST Action CA15102 is also greatly appreciated.

\section{References}

[1] NOVÁK, P., KRISTIANOVÁ, E. (2015). Properties, Production and Applications of NiTi Shape Memory Alloy. In: Manufacturing Technology, Vol. 15, No. 6, pp. 995-998. UJEP. Czech Republic.

[2] NOVÁK P., ŠKOLÁKOVÁ A., VOJTĚCH V., KNAISLOVÁ A., POKORNÝ P., MORAVEC H., KOPEČEK J., KARLÍK M., KUBATÍK T.F. (2014). Application of Microscopy and X-ray Diffraction in Optimization of the Production of NiTi Alloy by Powder Metallurgy. In: Manufacturing Technology, Vol. 14, pp. 387-392. UJEP. Czech Republic.

[3] ELAHINIA, M.H., HASHEMI, M., TABESH, M., BHADURI, S.B. (2012). Manufacturing and processing of NiTi implants: A review. In: Progress in Materials Science, Vol. 57, pp. 911-946. Elseviers, Netherlands.

[4] https://ec.europa.eu/growth/sectors/raw-materials/specific-interest/critical_cs

[5] NOVÁK, P., VESELÝ, T., MAREK, I., DVOŘÁK, P., VOJTĚCH, V., SALVETR, P., KARLÍK, M., HAUŠILD, P., KOPEČEK, J. (2016). Effect of Particle Size of Titanium and Nickel on the Synthesis of NiTi by TE-SHS. In: Metallurgical and Materials Transactions B, Vol. 47B, pp. 932-938. Springer, USA.

[6] WHITNEY, M., CORBIN, S.F., GORBET, R.B. (2008). Investigation of the mechanisms of reactive sintering and combustion synthesis of NiTi using differential scanning calorimetry and microstructural analysis. In: Acta Materialia, Vol. 56, pp. 559-570. Elseviers, Netherlands.

[7] NOVÁK, P., MEJZLÍKOVÁ, L., MICHALCOVÁ, A., ČAPEK, J., BERAN, P., VOJTĚCH, D. (2013) Effect of SHS conditions on microstructure of NiTi shape memory alloy. In: Intermetallics, Vol. 42, pp. 85-91. Elseviers, Netherlands.

[8] NOVÁK, P., MICHALCOVÁ, A. MAREK, I., VODĚROVÁ, M., VOJTĚCH, D. (2012). Possibilities of the observation of chemical reactions during the preparation of intermetallics by reactive sintering. In: Manufacturing Technology, Vol. 12, No. 13, pp. 197-201. UJEP. Czech Republic.

[9] MASSALSKI, T.B. (1990). Binary Alloy Phase Diagrams. ASM, USA. 